\title{
A COMMENTARY \\ THE INADMISSIBILITY OF NON- \\ INDONESIAN CITIZENS IN \\ JUDICIAL REVIEW BEFORE THE \\ INDONESIAN CONSTITUTIONAL \\ COURT
}

\author{
Bayu Mahendra \\ PhD Candidate in International Criminal Law \\ School of Law Middlesex University, London, United Kingdom \\ oktaviusbayumahendra@gmail.com
}

\begin{abstract}
The Constitutional Court of Indonesia, in its judgment No 2-3/PUU-V/2007, ruled that non-Indonesian citizens have no legal standing to file judicial review before the Court. In determining the legal standing, the Court rejected applicants' constitutional loss which should actually serve as the substantial examination in judicial review but rather addressed this question on the basis of applicant's citizenship. This inadmissibility ruling, however, raises question on what legal standing actually mean in the context of judicial review. This paper reviews the Court's consideration in determining legal standing status and examines future legal consequences of such reasoning. By revisiting the substance of legal standing and judicial review derived from the 1945 Constitution, relevant Statutes, Court's practices and case law, as well as the dissenting opinion of the judges in this case, it is found that the Court overruled the substance to procedural examination on the basis of citizenship and therefore failed to address the actual question of legal standing. This paper concludes that the Court's reasoning has abandoned the constitutional loss as the very substance of legal standing and to which amounts to immunity of legal standing provision from a judicial review. Consequently, non-Indonesian citizens will never be recognized in judicial review mechanism before the Indonesian Constitutional Court.
\end{abstract}

Keywords: Non-Indonesian Citizens, Judicial Review, Immunity 


\section{INTRODUCTION}

On the $23^{\text {rd }}$ of October 2007, the Indonesian Constitution Court (hereinafter "the Court") had rendered a decision upon judicial review submission registered under the Judgment No 2-3/PUU-V/2007. It was then delivered a week later in a trial hearing on Tuesday, dated on the $30^{\text {th }}$ of October 2007. The substance of the case questioned the legality of death penalty that was in force under article 80 (1) (a); article 8o (2) (a); article 8o (3) (a); article 81 (3) (a); article 82 (1) (a); article 82 (2) (a); article 82 (3) (a) of the Indonesian Statute No 22 Year 1997 on Narcotics towards the 1945 Constitution of the Republic of Indonesia. ${ }^{1}$ Two Indonesians and three Australian citizens filed for judicial review before the Constitutional Court, challenging the legality of death penalty in force under the Narcotics Law. The first two Indonesians were Edith Yunita Sianturi and Rani Andriani, while the three Australians were Myuran Sukumaran, Andrew Chan and Scott Anthony Rush. ${ }^{2}$ All of them were convicted by the public court for capital punishment under the aforementioned law. Although the merit of their judicial review was rejected by the Constitutional Court, however, this case is considered as one of the most influential precedents for the Constitutional Court in determining forthcoming cases. ${ }^{3}$ This became the first case before the Constitutional Court filed by non-Indonesian citizens. ${ }^{4}$

The judgment declared that the case was admissible before the Constitutional Court but for the Indonesian applicants. They were granted to file judicial review under article 51 (1) (a) of the Indonesian Statute No 24 Year 2003 concerning the Constitutional Court stating that the applicants shall be Indonesian citizens. There were not much questions with regards to the application of this article for

\footnotetext{
${ }_{1}$ Judicial Review Number 22 of 1997 on Narcotics against the 1945 Constitution, No. 2-3/PUU-V/2007 (The Constitutional Court of the Republic of Indonesia 2007).

2 Judicial Review Number 22 of 1997 on Narcotics against the 1945 Constitution at 1-2.

3 See, inter alia, Judicial Review Number 1 of 1979 on Extradition, No. 73/PUU-VIII/2010 (The Constitutional Court of the Republic of Indonesia 2010). See Judicial Review Number 24 of 2003 on the Constitutional Court as it has been amended into Law Number 8 of 2011 on the Amendment of Law Number 24 of 2003 on the Constitutional Court against the 1945 Constitution, No. 137/PUU-XII/2014 (The Constitutional Court of ther Republic of Indonesia 2014).

4 In 2011, four years later after the Judgment No 2-3/PUU-V/2007 delivered, the Constitution Court has unanimously rendered a Judgment No 73/PUU-VIII/2010 filed also by non-Indonesian citizen, a Romanian, Popa Nicolae, concerning on his arbitrary detention of article 34 (b), article 35 (1), and article 39 (4) of the Indonesian Statute No 1 Year 1979 on Extradition and article 51 (1) (a) the Indonesian Statute No 24 Year 2003 concerning the Constitutional Court. The Constitutional Court declared the case inadmissible as the applicant had no legal standing to file for such judicial review.
} 
the Indonesian citizens. The Court then examined the merit of judicial review for those Indonesian applicants and found to reject the case. On the other hand the Court declared that the case was inadmissible for the three Australian citizens. The Court found that they were not entitled to submit judicial review under the same article. This decision separated the Chambers' opinion into six to three in terms of applicants' legal standing. ${ }^{5}$

\subsection{The Applicants Submissions}

The Australian citizens proclaimed that article 51 (1) (a) of the Indonesian Statute No 24 Year 2003 concerning the Constitutional Court was not in compliance with the Indonesian Constitutional Court $1945 .{ }^{6}$ They further argued that they should have standing before the Court on the basis of these eight following grounds: $i$ ) the applicable regime of human rights law in the 1945 Constitution; ii) non-discrimination principle; iii) and the equality before the law as afforded by the 1945 Constitution; iv) the definition of constitutional loss; $v$ ) due process of law; vi) the threshold vii) the practice of other constitutional courts; viii) and the gravity of the rights and sentence.

First of all, they argued that the wording of "each person" adopted in the 1945 Constitution shall refer to human rights law regime, leaving the concept of citizenship and nationality.7 They claimed that article 51 (1) (a) which differs on the basis of citizenship was not in accordance with the 1945 Constitution. The 1945 Constitution provided that each person is subjected for human rights protection as long as he/she lives within Indonesia territory. This was confirmed by Article 26 (2) of the 1945 Constitution when defining resident as both Indonesian citizens and non-Indonesians who are within Indonesia territory, regardless its citizenship or nationality. ${ }^{8}$

Another point was raised relating to the principle of non-discrimination before the law. They made reference to article 28D (1) of the 1945 Constitution, stating that each person is entitled to be equally treated before the law without

\footnotetext{
5 Judicial Review Number 22 of 1997 on Narcotics against the 1945 Constitution at 432.

6 Ibid., 15.

7 Ibid.

8 Ibid., 16.
} 
any discrimination. Consequently, the constitutional loss defined in article 51 (1) may occur to either Indonesian citizens or non-Indonesian citizens, ${ }^{9}$ or in other words to each person regardless its citizenship or nationality as long as he/she is afforded constitutional rights under the 1945 Constitution. ${ }^{10}$

They further recalled the applicable hierarchy in the Indonesian legal system, which placed statutes as the manifestation of the 1945 Constitution. Subsequently, the protection of rights set forth under the statutes rooted from the 1945 Constitution shall also apply to both Indonesian and non-Indonesian citizens. There would be then inconsistency and contradiction to argue that the rights afforded by the 1945 Constitution apply exclusively to Indonesian citizens. If it is true that the 1945 Constitution and the rights set forth therein are reserved exclusively to Indonesian citizens, then statutes, that are the manifestation of the 1945 Constitution, shall be reserved merely for its citizens and not be applicable to non-Indonesian citizens. In this sense, they (Australian citizens) simply could not be prosecuted under the concerned statute. ${ }^{\text {II }}$ Moreover, instead of "each person", the term of "each citizen" should have been adopted in the 1945 Constitution if it is intended and applied exclusively for Indonesian citizens. ${ }^{12}$

They also reiterated that under article 24 (1) and 24 (1) (a) of the 1945 Constitution, judicial power is mandated to the Supreme Court and the Constitutional Court. Referring to those aforementioned articles, due process of law in seeking justice may also stand before the Supreme Court and the Constitutional Court of Indonesia. It goes saying to prove that each person, regardless its citizenship and nationality, is entitled to seek justice by means legal proceedings before Supreme Court and/or the Constitutional Court. It constituted breach of constitutional right when the Constitutional Court rejected judicial review by non-Indonesian citizens on the basis of citizenship or nationality.

They proposed certain conditions to what extent non-Indonesian citizens may exercise for judicial review. They argued that judicial review should be

\footnotetext{
9 Ibid., 16-18.

${ }_{10}$ Ibid., 18-19.

${ }^{11}$ Ibid., 18.

12 lbid.
} 
granted to non-Indonesian citizens, when non-Indonesian citizens become the subject of a statute and when the statutes concern with the fundamental rights that inherent to each individual regardless its citizenship and nationality. ${ }^{13}$ Providing the practice of Germany, Mongolia and Australia constitutional court which grant legal standing for non-nationals to file for judicial review before their constitutional courts, the applicants sought for similar approach to be adopted by the Court in their case. ${ }^{14}$ Lastly, the gravity of the sentence itself was the self-evident and argued as one of the grounds for the legal standing of the applicants. The verdict of capital punishment had shown that they (Australian citizens) were having interest for such judicial review in this case. ${ }^{15}$

\subsection{The Chamber's Opinion}

In its judgment No 2-3/PUU-V/2007, the Chamber recalled to article 51 (1) of the Indonesian Statute No 24 Year 2003 concerning the Constitutional Court in addressing the question of legal standing of the applicants. In enforcing this article, the Court referred to its judgment No oo6/PUU-III/2005 concerning the conditions of which the claim for constitutional loss could be exercised. ${ }^{16}$ The Court ruled that in order to establish constitutional loss, the applicants shall satisfy these five following requirements cumulatively. ${ }^{17}$ First, that the applicant possesses the constitutional rights and/or authorities as proscribed under the 1945 Constitution. Second, the applicant considers his or her constitutional rights and/or authorities have been deprived by the challenged statute. Third, such constitutional deprival or loss should be specific and actual or imminently potential, on the basis of logical order is likely to occur. Fourth, there should be a causal verband or causality between the loss and the enactment of the concerned statute. Fifth, there should be the possibility when a favorable court decision is rendered, the constitutional loss would not occur or repeated.

\footnotetext{
${ }_{13}$ Ibid., 19-20.

${ }_{14}$ Ibid., 20.

15 Ibid.,95.

${ }^{16}$ Ibid.,367. See Judicial Review Number 32 of 2004 on Regional Government against the 1945 Constitution, No. 006/PUU-III/2005 (The Constitutional Court 2005).

${ }_{17}$ Ibid. See Judicial Review Number 56 Prp of 1960 on the Determination of Agricultural Land Area against the 1945 Constitution, No. 11/PUU-V/2007 (The Constitutional Court of the Republic of Indonesia 2007). Those aforementioned requirements are cumulative; meaning that all of those five conditions must be fulfilled in establishing constitutional loss.
} 
The Court found that the two Indonesian citizens possessed the constitutional rights proscribed under article 28A and 28I (1) of the 1945 Indonesian Constitution regarding the right to life. ${ }^{18}$ The Chamber believed that the rights derived from those aforementioned articles are non-derogable rights. It proclaimed that the enactment of the death penalty under the Law of Narcotics could possibly be considered as an actual loss to them. ${ }^{19}$ The Chamber also found that these two Indonesian citizens have satisfied the requirement of article $5^{1}$ (1), specifically in point (a) which states that the applicant shall be Indonesian citizen. In this regards, the Court granted legal standing for these two Indonesian citizens and declared their submission was admissible for judicial review before the Constitution Court.

However, the Court did not grant legal standing when examining the applicants of the three Australian citizens. The Court held its finding on these three following grounds: i) that article 51 (1) expressis verbis or clearly states that grants solely for Indonesian citizens to file for the judicial review before the Constitutional Court; ii) the inadmissibility of non-Indonesian citizens to examine the laws does not necessarily means that they do not have legal protection under the principle of due process of law, in this case they could resort for appeal, cassation and review before the supreme court; iii) the wording of each person and group of people with similar interest in the official explanation of this provision must be interpreted in connection with the individual Indonesian citizens, thus, the applicants were not qualified under article 51 (1). As they had no legal standing before the Constitutional Court, ${ }^{20}$ the case was then declared inadmissible.

\subsection{The Dissenting Opinions}

With regards to the merit of the case on the legality of the death penalty, the Judges' opinions have been divided into five to four. There were four Judges submitted their dissenting opinions, where three of them addressed their dissenting views with regards to the legal standing of the applicants.

\footnotetext{
${ }_{18}$ Judicial Review Number 22 of 1997 on Narcotics against the 1945 Constitution at 367.

19 Ibid.

20 Ibid., 367-68.
} 
One of the dissenting judges, Justice Harjono, argued that the wording of the constitutional rights as proscribed under article $28 \mathrm{~A}$ to $28 \mathrm{~J}$ in the Indonesian Constitution 1945 adopted the term of "each person". This adoption implies that the recognition of the rights is entitled to individual, including to non-Indonesian citizens, regardless their citizenships and nationalities. ${ }^{21}$ Nevertheless, this should not mean that non-Indonesian citizens vis a vis possess the same treatment and have the same rights ${ }^{22}$. He argued that there must be certain limitations on the application. Under the Indonesian legal system, he claimed, the laws could be differentiated into these three following types. First, the laws that are intended exclusively to Indonesian citizens. Non-Indonesian citizens would simply have no legal standing to challenge the first laws. Second, the laws are designated merely to non-Indonesian citizens. These laws may reflect as sovereignty and supremacy of a state, including its policies towards non-Indonesian citizens. They might be granted legal standing to challenge on this second laws, but it would be likely unsuccessful because it relates to state sovereignty and supremacy. And third, the laws that are implemented for both Indonesian citizens and non-Indonesian citizens. When non-Indonesian citizens challenge this third type of laws, it will rule both Indonesian citizens and non-Indonesian citizens, and the result of such examination would be concrete and genuinely affectted both parties. ${ }^{23} \mathrm{He}$ acknowledged that the constitutional court judgment is erga omnes in nature. Once the Court has declared that a law does not bind legally, the Court ruling shall not apply exclusively for the applicants whom their rights have been deprived, but it shall apply to all Indonesian citizens. Therefore, when there is an application before the Constitutional Court filed by non-Indonesian citizens to examine the substance of the laws that might impact to the Indonesian citizens, they should be then granted the legal standing. ${ }^{24}$

He further argued that the effect of such inadmissibility would delay the legality of law because it had to wait for qualified parties, by means Indonesian

\footnotetext{
${ }^{21}$ Dissenting Opinion of Justice Harjanto in Constitutional Court Judgment on the Legality of Death Penalty under the Law of Narcotics ( $n$ 1) at 434

${ }^{22}$ Ibid., 434

23 Ibid., 434-435

24 Ibid., 435
} 
citizens, who have the interest to file such examination. ${ }^{25}$ Instead of annulling the application of article 51 (1), he suggested the Court to adopt a broader view to the application of this article ${ }^{26}$, granting the standing to non-Indonesian citizens. Such argumentation showed genuine spirit of the original notion of judicial review.

Justice HM. Laica Marzuki, in his dissenting opinion, argued that if one strictly referred to article 51 (1) (a) then the right for judicial review would not be granted to non-Indonesian citizens. He noted, however, when the substance of the judicial review is in connection with the right to life of any individual proscribed under article 28A and 28I in the Indonesian Constitution 1945 then article 51 (1) (a) could be overruled. ${ }^{27}$ He reiterated that article 51 (1) (a) could not prevent the examination because it was a question of life and death concerning the right to life as an absolute right and inherent dignity of human being. He then contended that article 28D (1) of the 1945 Constitution ensures equal treatment for each person before the law. The meaning of "each person" article 28D (1) of the 1945 Constitution shall not exclusively refer to the concept citizen right; indeed, it is equal right for each person who lives within Indonesia territory. ${ }^{28}$ He further provided example of the constitution judgments on legal standing filed by non-Germany citizens and non-Mongolia citizens, and even stateless individual who illegally lived within the territory of Mongolia, were declared admissible by Germany Constitution Court and Mongolian Constitutional Court respectively. ${ }^{29}$

A similar interpretation adopted by Justice Maruarar Siahaan in examining the request of judicial review by three Australian citizens. He held that the adoption of human rights into the Indonesian Constitution 1945 as the basic norm implies that human rights serve as the threshold in examining legality of laws towards the constitution. In so doing, the constitutional rights afforded

\footnotetext{
25 Ibid., 435-436

${ }^{26} \mathrm{Ibid}$.

${ }^{27}$ Dissenting Opinion of Justice HM. Laica Marzuki in Constitutional Court Judgment on the Legality of Death Penalty under the Law of Narcotics ( $n$ 1) at 442-443.

${ }_{28}$ Ibid., 443

29 lbid.
} 
by article 51 (1) (a) shall not solely apply nationally but also universally. ${ }^{30} \mathrm{He}$ recalled article 28 I (2) of the Indonesian Constitution 1945 which ensures nondiscriminative treatment to each person.

Furthermore, the ratification of the International Covenant on Civil and Political Rights (ICCPR) by the Republic of Indonesia on the $28^{\text {th }}$ of October 2005 as embodied under the Indonesian Statute No 12 Year 2005 shall point human rights to serve as one of decisive factors in judicial review. Consequently, legal standing on this case shall be expanded to non-Indonesian citizens when the substance of judicial review related to fundamental rights. ${ }^{31}$

However, he then provided for limitation of under what circumstance nonIndonesian citizens shall not have rights to question state policies concerning on citizenship. He referred to the Constitution of the Republic India which differentiates the Fundamental Rights into these two: exclusively applicable for Indian citizens and for each person including non-Indian citizens. ${ }^{32}$ This inferred that notwithstanding the wording of "each person" is hold under the Indonesian Constitution 1945, the rights possessed between Indonesian citizens and non-Indonesian citizens should be also easily differentiated. For instance, inter alia, in the political rights, the rights for election and to be elected that are embodied in the Indonesian Constitution 1945 shall apply exclusively for Indonesian citizens, and certainly not for non-Indonesian citizens. The court practices would assist to differentiate between the fundamental rights entitled for Indonesian citizens and the fundamental rights for non-Indonesian citizens that are guaranteed by the Indonesian legal system and its proceedings. ${ }^{33}$ Lastly, he emphasized that unsystematic law or its disorder tends to occur within legal system because the laws are made in different times. It is then left to the judges to interpret the laws reflecting the spirit of the constitution so that it could be implemented in logical and systematical order. ${ }^{34}$

\footnotetext{
$3^{30}$ Dissenting Opinion of Justice Maruarar Siahaan in Judicial Review Number 22 of 1997 on Narcotics against the 1945 Constitution at 446 . It reviews the Legality of Death Penalty.

${ }^{31}$ Ibid., 446-447

$3^{2}$ Ibid., 448

$33 \mathrm{lbid}$.

34 Ibid., 450-451
} 


\section{THE COMMENTARY}

It has already been discussed on the previous chapter how the Court ruled the question of legal standing to non-Indonesian citizens in judicial review before the Constitution Court of Indonesia. This chapter goes further to determine the actual question of legal standing under article 51 (1) of the Indonesian Statute No 24 Year 2003 concerning the Constitutional Court. Departing from this starting point, this chapter notes the inconsistency revealed from the Court reasoning, as well as the conflict of laws arising from the Court's finding.

\subsection{Legal Standing before the Indonesian Constitutional Court: Procedure Vs Substance}

Before turning to discuss the procedural and substantive examinations of legal standing in the Indonesian Constitutional Court, it would be necessary to see what the genuine reasons, purposes and position of legal standing examination in the court proceedings are, and to briefly look at the notion of legal standing itself. It is not questioned here, however, that the position of legal standing as the preliminary examination before the Court goes for the merits.

Generally speaking, (legal) standing is defined as "preliminary jurisdictional requirement, formulated at a high level of generality and applied across the entire domain of law".35 It is more jurisdictional determination rather than determination on the substance ${ }^{36}$ as the latter will amount to trial hearing. The examination of standing, as noted by William A. Fletcher, is intended to ensure that the (possibly) injured applicants could present the case effectively, able to make complaint or questioning the issue, that his/her case would inform the court for the consequence of its decisions, to control policy making functions ${ }^{37}$ and in practical, to control the Court's "appellate docket". ${ }^{8}$ In addition to those, it is important to note that another purpose of standing is in order to avoid the overlapping jurisdiction between the Court and other governmental branches. ${ }^{39}$

\footnotetext{
35 William Flethcer, "The Structure of Standing," The Yale Law Journal 98, no. 221 (1988).

${ }^{36}$ Ibid., 229

37 Ibid., 222

${ }^{38}$ Ibid., 228

39 Stefanus Hendrianto, "Convergence or Borrowing: Standing in the Indonesian Constitutional Court," Constitutional Review 1, no. 1 (2015): 41-42.
} 
The ruling of legal standing enshrines under article 56 (1) and 56 (2) of the Indonesian Statute No 24 Year 2003 concerning the Constitutional Court. Article 56 (1) and (2) respectively read:

Article 56

(1) When the Court finds that the applicant or/and his/her submissions does not satisfy the requirements as stipulated by article 50 and 51 , the Court shall declare that the case is inadmissible

(2) When the Court finds that the submission is reasonable, the Court shall declare that the case is admissible.

The Court may declare the case inadmissible when the applicants or their submissions do not satisfy the requirements of, inter alia, the legal standing as stipulated by article 51 in the same statute. However, pursuant to article 56 (2), the Court shall declare the case admissible when it finds reasonable basis in applicants submissions. It would be then correct to state that question on legal standing serves as preliminary examination before the Court goes to examine merit of the $\mathrm{case}^{40}$ in the context of entire trial proceedings. There is nothing to suggest that such preliminary examination denotes as procedural determination. The Court, however, seemed to indicate these two to be similar. It was shown when the Court relied on the expressis verbis of article $51(1) .{ }^{41}$ It was quite clear here that the Court considered more procedural examination on legal standing, leaving the question of possible constitutional loss of the applicants. The wording from George P Fletcher would seem appropriate to describe such approach that the procedural rules determine "the way game is played, and the game is always played the same way".42

However, such procedural determination is criticized, that at certain extent, would leave the actual nature of the problem. William A Fletcher suggested that in determining whether applicants have legal standing, the genuine question is whether the applicants have the rights to enforce the "asserted legal duty". The actual question of legal standing lies on the merit of the case. He argued that

\footnotetext{
$4^{\circ}$ Conf Bisariyadi, "Membedah Doktrin Kerugian Konstitusional," Jurnal Konstitusi 14, no. 1 (2017): 39. It argues that due to the inconsistence application of the Court with regards to constitutional loss' doctrine, the inadmissibility or niet onvankelijk verklaard decision may also be rendered by the Court when it concerns the examination of the merit.

${ }_{41}$ Judicial Review Number 22 of 1997 on Narcotics against the 1945 Constitution at 367-68.

${ }^{42}$ George Flethcer, Basic Concepts of Criminal Law (New York: Oxford University Press, 1998), 8.
} 
the interest protected by the laws is the same standard applied both to show that the applicants have the standing and consecutively to which the basis they rely their claims on the merit of the case. ${ }^{43}$ Condemning the standing as procedural matter at the first place would leave the nature of the problem unresolved. Reflecting at this line of argument, he then concluded that the question of standing is the question of substantive law and consequently the answer of the standing questions would depend on the substantive of the laws. ${ }^{44}$ This 'substance examination approach' on legal standing is what precisely Justice Harjono, Justice Maruarar Siahaan and Justice HM. Laica Marzuki held in their respective dissenting opinions. As the examination concerns the substantive laws (non-derogable rights) proscribed under the 1945 Constitution, the procedural questions could be simply overruled.

Indeed, in legal standing determination, such substantive approach seems to be more compelling with the construction of article 51 (1) and its following five requirements set by the Court in judgment No 0o6/PUU-III/2005. Article 51 (1) of the Indonesian Statute No 24 Year 2003 concerning the Constitutional Court, defines the parties entitled to exercise judicial review. It is read as follows:

(1) Applicant is the party who considers that his/her constitutional right or authority has been deprived by the enactment of statute, namely:

a. Individual Indonesian citizens;

b. Customary community groups living in accordance with the society development and principles of the State of the Republic of Indonesia as provided by the laws;

c. Public or private legal entities; or

d. State institutions

\footnotetext{
43 Some commentators noted that this would be the same question addressed by the Court in determining legal standing and the merit of the case. See, inter alia, Flethcer, "The Structure of Standing," 236. It would be odd when the Court granted the admissibility of the case but later rejected the case in the examination of the merit, because the same standard applied to both in determining the legal standing and merit of the case, there is overlapping standard applied for both examinations. See also Bisariyadi, "Membedah Doktrin Kerugian Konstitusional," 38. However, the admissibility test does not work that way. When looking at the nature of legal standing under article 56 (1) of the Indonesian Statute No 24 Year 2003 concerning Indonesian Constitutional Court, it would be seen that legal standing stands as procedural matter within court proceedings. Indeed, the threshold employed in determining between such procedural context and substance would not be the identical. In the context of procedural examination of legal standing for instance, the threshold applied by the Court is "reasonable basis to believe" (article $56(2)$ ). It is in fact the preliminary examination that there are possible constitutional losses possessed by the applicants.

44 Flethcer, "The Structure of Standing," 225, 290-91. He argued that the doctrine of legal standing is the result of the overlapping development of the administrative state and the litigation to enforce public and primarily constitutional values. See also Philipus Hadjon, Pengantar Hukum Administrasi Indonesia-Introduction to the Indonesian Administrative Law zrd Edition (Surabaya: Gadjah Mada University Press, 1994), 335.
} 
In order to determine the ratio legis ${ }^{45}$ or substance of an article, it can be easily identified that the substance is usually able to serve independently the article without requiring any other clauses. On the contrary, procedural cannot stand by itself in an article. When looking at the formulation of article 51 (1), one may easily find that this article comprises of substantive elements defining the applicants and its required pre-condition, and procedural elements providing list of subjected parties who are able to bring the judicial review. Without the procedural elements of the list parties, the article yet able to stand although it solely comprises with the definition of applicants and constitutional loss.

The first element of this provision, suggested as the substance, defines the parties who consider that their constitutional rights and/or authorities have been deprived by the enactment of statutes. It refers into pre-conditional requirements of possible constitutional injury. There is no mention to what constitute constitutional rights are. In order to determine the scope of constitutional rights and/or authorities, one should look at the official explanation of article 51 of the Indonesian Statute No 24 Year 2003 concerning the Constitutional Court. The explanation defines the terms of 'constitutional rights'. Pursuant to its official explanation, the meaning of constitutional right shall refer to the rights that proscribed under the 1945 Constitution of the Republic Indonesia.

Article 51 (1) further rules that such constitutional rights should be considered for being deprived by the enactment of statute. In other words, this article governs that the applicants should demonstrate the possible constitutional loss. Meanwhile in order to define constitutional loss, the Court recalls its judgment No 006/PUU-III/2005 which specifically addresses the requirements of constitutional loss. ${ }^{46}$ Constitutional loss could be established when it satisfy these five cumulative conditions. First of all, the applicant shall have the constitutional rights and/or authorities proscribed under the 1945 Constitution. Second, the

\footnotetext{
45 Satjipto Rahardjo, Ilmu Hukum, 6th ed. (Bandung: Citra Aditya Bakti, 2006), 45. He believed that each legal instrument has ratio legis, the basic principle of law underlying the instruments or also known as the spirit in the legal instruments.

${ }^{46}$ This set of requirements is arguably rooted from the case requirement of article III of the United States Constitution, to which requiring the applicants to show the injury in fact; the causality between the injury and the challenged statute; and the redressability sought. See also Hendrianto, "Convergence or Borrowing: Standing in the Indonesian Constitutional Court," 33. ; Bisariyadi, "Membedah Doktrin Kerugian Konstitusional," 27.
} 
applicant believes that his or her constitutional rights and/or authorities have been deprived by the challenged statute. Third, such constitutional deprival or loss should be specific and actual or imminently potential to occur on the basis of logical order. Fourth, that there should be a causal verband or causality between the loss and the enactment of the concerned statute. Lastly, there should be the possibility when a favorable court decision is rendered, the constitutional loss would not occur or repeated. ${ }^{47}$

The formulation of article $5^{1}$ (1) mentions list of four subjects who are able to submit judicial review before the Court. Nevertheless, such determination seems to be more supportive in nature, cannot stand by itself and therefore serves rather as procedural matters than substantive one. According to this second element, there are four subjects entitled to enforce judicial review, namely individual, including the group of people who possess the same interest, ${ }^{4}$ Indonesian citizens; customary community groups living in accordance with the society development and principles of the State of the Republic of Indonesia as provided by the laws; public or private legal entities; and State institutions. If this logical formulation is affirmed, it seems then that the three dissenting judges relied on substantive part of article $5^{1}$ in determining the actual question of legal standing, meanwhile the Court decision emphasized that the question of legal standing lies on the procedural matters

\subsection{Inconsistency in the Chamber's Opinion}

The Chamber's found the case was inadmissible for three Australian citizens on these three following grounds. First, that article $5^{1}$ (1) (a) expressis verbis or has stated clearly that it is Indonesian citizens solely, in terms of citizenship, who are able to file for judicial review before the Constitutional Court. Second, the inadmissibility of non-Indonesian citizens to examine the laws does not necessarily mean that they loss their legal protections under the principle of due process of law, in this case they were granted the legal remedies of appeal, cassation and review before the supreme court. Third, that the wording of "each

\footnotetext{
47 Judicial Review Number 22 of 1997 on Narcotics against the 1945 Constitution at 367-68. It is about on the Legality of Death Penalty under the Law of Narcotics.

${ }^{48}$ Official Explanation of article 51 (1) (a) of "Indonesian Law Number 24 of 2003 on the Constitutional Court" (2003).
} 
person and group of people with similar interest", as stipulated in its official explanation of the statute, must be interpreted in connection with the individual Indonesian citizens. ${ }^{49}$

\subsubsection{The Expressis Verbis of Article 51 (1) (a)}

In determining the legal standing, the Court argued that article $5^{1}$ (1) (a) of the Indonesian Statute No 24 Year 2003 concerning the Constitutional Court expressis verbis stated that Indonesian citizens are solely entitled to file for judicial review. ${ }^{50}$ The Court limited its argumentation on the basis of its expressis verbis of the concerned article. As mentioned in the previous sub chapter, article 51 (1) (a) serves as the procedural part of article 51. Briefly speaking, the Court answered the question of legal standing of the applicants by stating that because the rules say so.

It is true when the Court resorted to expressis verbis of article 51 (1) (a), then the Australian citizens simply do not fall within the scope of this article. This, however, does not seem to be correct examination in addressing questions of legal standing. To what extent such procedural argumentation is legitimate in determining legal standing status? It is essential here to recall the nature of judicial review.

The hierarchy of the norms of the Stufenbaulehre Theory ${ }^{51}$ has significantly affected into Indonesian legal system. This theory states that the norms have the hierarchy of different levels, and they are not standing side by side on the same level. It must constitute a unity between the norms, in which Hans Kelsen emphasizes "that the creation of one norm, the lower one, is determined by the higher and terminated by a highest, the basic norm, which being the supreme reason of validity of the whole legal order".52 In Indonesian legal system, the concrete evidence of a hierarchical legal order is in force under article 7 of the Indonesian Statute No 12 Year 2001 concerning the Establishment of the

49 Judicial Review Number 22 of 1997 on Narcotics against the 1945 Constitution at 367-68.

${ }_{50} \mathrm{Ibid}$.

${ }^{51}$ The Stufenbaulehre Theory or known as Teori Stufenbau in Indonesian legal system, developed by Hans Kelsen, is arguably initiated by and drawn from Hans Kelsen's disciple, Adolf Julius Merkl in his article Das doppelte rechtsantlitz. See Jakab Andras, European Constitutional Language (Cambridge University Press, 2016), 326.

${ }^{52}$ Hans Kelsen, General Theory of Law and State (2oth Century Legal Philosophy Series Vol. I) (Cambridge: Harvard University Press, 1949), 124. 
Regulations. The type and the hierarchical order of the Indonesian regulations consist of the 1945 Constitution of the Republic Indonesia; MPR Decisions; 53 Laws/Government Regulations in lieu of law;54 Executive Regulations; Presidential Regulations; Provincial Government Regulations; and Regional/Municipal Government Regulations. This theory, however, has also reiterated that in practice there is no guarantee that the lower norms would be in compliance with the higher one. ${ }^{55}$ In order to constitute such unity, it is required for 'check and balance' in legal system by means, inter alia, the judicial review. ${ }^{56}$ Reflecting on these circumstances, it is then fundamental for the existence of judicial review in legal system, although the concept and definition of judicial review itself vary from each state to another. Nevertheless, among those different practices between states, it could be derived that judicial review may refer to the examination of the legal instruments by the court. ${ }^{77}$

Under the Indonesian legal system, the term of judicial review refers into these two meanings, i) the examination of whether a law is in compliance with the constitution; $5^{8}$ ii) and/or that the rules or legal instruments, -inferior than the law in a hierarchical system, is in accordance with the law. 59 The first falls within the jurisdiction of the Indonesian Constitution Court, while the latter is mandated to the Supreme Court. Judicial review (in this context is constitutional review) before the Constitutional Court, has its purpose to examine the legality of the laws towards the Indonesian Constitution 1945 mandated by article 24C (1) of the 1945 Indonesian Constitution, article 10 (1) (a) of the Indonesian Statute No 24 Year 2003 concerning the Constitutional Court and article 29 (1) (a) of the Indonesian Statute No 48 Year 2009 concerning Judicial Power.

\footnotetext{
53 MPR (Majelis Permusyawaratan Rakyat) refers as the People's Consultative Assembly of the Republic Indonesia.

${ }_{54}$ Although the regulation in lieu of law is first initiated by the President (executive), nevertheless, it shall, be submitted, at the closest hearing, before the House of Representatives of the Republic Indonesia for the approval, or rejection.

55 Hans Kelsen, Pure Theory of Law (2nd German Edition Max Knight). (New Jersey: The Law Book Exchange, Ltd, 2005), 205-6. See also also the Dissenting Opinion of Justice Maruarar Siahaan in Judicial Review Number 22 of 1997 on Narcotics against the 1945 Constitution at 446. It explains the Legality of Death Penalty under the Law of Narcotics

${ }^{56}$ King Faisal Sulaiman, Teori Peraturan Perundang-Undangan Dan Aspek Pengujiannya (Yogyakarta: Thafa Media, 2017), 103.

57 Jimly Asshiddiqie, Hukum Acara Pengujian Undang-Undang (Jakarta: Konstitusi Pers, 2006), 1.

${ }^{58}$ Article 24 C(1) of "The 1945 Constitution of the Republic of Indonesia" (1945).; artivle 10(1)(a) of Indonesian Law Number 24 of 2003 on the Constitutional Court.; and Article 29(1)(a) of "Indonesian Law Number 48 of 2009 on Judicial Power" (2009).

${ }^{59}$ Article 29 (1) (a) of the Indonesian 20 (2) (b) Indonesian Law Number 48 of 2009 on Judicial Power.
} 
Referring to the aforementioned nature of judicial review before the Constitutional Court, it can be drawn that statutes are subjected to examination towards the 1945 Constitution. Such examination is intended to check whether concerned statute is in compliance with the 1945 Constitution. In this regards, it would be then clear that the 1945 Constitution serves as the threshold for statutes examination. ${ }^{60}$ It would be misleading for referring to other statutes in statute examination. It is considered as error of law when the Court adjudicated the question of legal standing of non-Indonesian citizens simply from the expressis verbis of article 51 (1) (a). This would be examining a statute towards the statute instead of the constitution.

In fact, if it is true that the 1945 Constitution and the rights set forth therein are reserved exclusively to Indonesian citizens, then statutes, that are the manifestation of the 1945 Constitution, shall be reserved exclusively for its citizens and not be applicable to non-Indonesian citizens. Accordingly, they simply could not be prosecuted under the concerned statute at the first place. This indicated court's error of law when it relied on procedural matter of article 51 (1). Indeed, the question of legal standing relied by the non-Indonesian citizens upon article $5^{1}$ (1) (a) should be subjected first for preliminary examination by the Court in order to check the compliance of the concerned article towards the 1945 Constitution before determining the status of legal standing. Alternatively, the Court may also consider a more lenient approach suggested by Justice Harjono. Rather than declaring article 51 (1) unconstitutional, the Court may adopt a broader interpretation stipulating that the non-Indonesian citizens' applicants should fall within the course of article 51 (1) as a consequence of the 1945 Constitution application. ${ }^{61}$ Thus, the wording of article $5^{1}$ (1) (a) is not per se a self-evident.

The Court argument of expressis verbis, however, has abandoned the ratio legis, the very substance, or the genuine meaning of article 51 (1). When the Court adopted procedural examination to determine status on legal standing, it

${ }^{60}$ Dissenting Opinion of Justice Maruarar Siahaan in Judicial Review Number 22 of 1997 on Narcotics against the 1945 Constitution at 446.

${ }^{61}$ Dissenting Opinion of Justice Harjanto, Judicial Review Number 22 of 1997 on Narcotics against the 1945 Constitution at $435-36$. 
implies that there must be specific rules of procedure to be satisfied. It appears there is nothing error with this approach. In fact, this is concrete evidence of Gustav Radbruch long standing theory of law. According to Radbruch, there are three basic principles underlying the law, namely justice, utility and certainty. This theory is also known for its tense situation between those three main principles, called as the spannungverhältnis. ${ }^{62}$ It states when one hold the law for its certainty, there must be lack either to justice or utility of law on the other side. The same thing when the Court adopted its expressis verbis reasoning in this case. The Court seemed to hold for the uniformity in order to keep the rules of the game to be played in the same way. Consequently, the Court might achieve certainty and consistency application of law in terms of procedural context, but leaving behind the justice and utility principle of law. It would be appropriate here to refer this as the evidence of 'overruled substance'.

Considering citizenship concept as the starting point, imply that the parties, other than Indonesian citizens, would simply have no legal standing before the Indonesian Constitutional Court. It could also be drawn that the parties of nonIndonesian citizens could not have the constitutional loss or injury under the Indonesian legal system. This is certainly a deprival of the 1945 Constitution's mandate to provide protection to each person in Indonesian territory.

Moreover, holding the second element of article 51 (1) (a) in legal standing determination would be simply superfluous. The second element, which comprises of subjected parties, could not stand as the ratio legis of article 51 (1). Legal standing requires what called as constitutional loss. Thus, when the Court argued that the second element is rather the substance of article 51 (1), then without constitutional loss, the individual Indonesian citizens, customary community groups living in accordance with the society development and principles of the State of the Republic of Indonesia as provided by the laws, public or private legal entities and State institutions should be automatically granted for legal standing before the Constitutional Court. If this argument is affirmed, it would be breach of the doctrine zonder belang het is geen rechtsingang, reads that

62 Ibid., 19 
without interest there would be no entry right. ${ }^{63}$ In any circumstances, it is sufficiently reasonable to reject legal standing of an applicant on the basis of lacking constitutional loss rather than solely based on the subjected parties. Standing, in its origin however, does not stand in the individual Indonesian citizens, customary community groups living in accordance with the society development and principles of the State of the Republic of Indonesia as provided by the laws or even public or private legal entities and State institutions, but it lies in each legal subject with possibly constitutional injury by which he/she is subjected to the enactment of certain provisions of a statute. A party cannot have standing to challenge the constitutionality of a statute unless he is subjected to the provisions of that statute.

It is then suggested here that the ratio legis of article 51 (1) should actually goes to the first element. When the Court declared that the case was admissible for the Indonesian citizens, the Court argued that they have constitutional rights afforded by article 28A and article 28I of the 1945 Constitution (non-derogable in nature) that have been deprived by the enactment of death penalty under the Law of Narcotics, as they were convicted for death penalty and awaiting for its execution. ${ }^{64}$ In this regards, they have legal standing to file judicial review before the Constitutional Court. This line of argumentation draws that constitutional loss is the basic concept of the application article 51 (1). The Court relied on the substance of this article to determine the legal standing of the applicants. It would be hard to argue that non-Indonesian citizens' applicants had no constitutional loss. Either Indonesian or non-Indonesian citizens' applicants questioned the same provisions, and all of them were convicted with the death penalty under the Narcotics Law. How could be possible to determine applicant legal standing but leaving the substance of injury? Meanwhile in order to determine the legal standing it should be demonstrated the connection of the injury and the enactment of concerned statute. This is what William A Fletcher defined that the examination of legal standing depends on the substance of the law. ${ }^{65}$

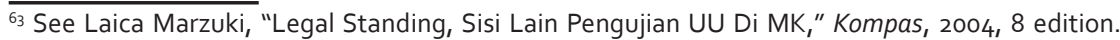

${ }_{64}$ Judicial Review Number 22 of 1997 on Narcotics against the 1945 Constitution at 367.

${ }^{65}$ Flethcer, "The Structure of Standing," 290-91.
} 
Supporting the argument that constitutional loss stands as the actual question of legal standing, and therefore decisive in admissibility test, the following case might serve to be the evidence. Some seven years later after this case, the Court rendered constitutional court judgment No. 137/PUU-XII/2014 reviewing article 51 (1) of the Indonesian Statute No 24 Year 2003 concerning the Constitutional Court. There were seven lawyers, all of them were Indonesian citizens, submitted judicial review to the Court questioning the constitutionality of article 51 (1). They requested for the Court to declare that their client, non-Indonesian citizen, should have the right to exercise judicial review. Although the applicants were Indonesian citizens, the Court yet declared that the case was inadmissible due to 'lacking of sufficient interest', as stipulated by article 51 (1) and its jurisprudence No oo6/PUU-III/2005. The Court found that although they were Indonesian citizens who represented non-Indonesian citizens they had no constitutional loss, required in article 51 (1) and court jurisprudence No 006/PUU-III/2005. Without legal interest or constitution loss, Indonesian citizens' applicants yet declares inadmissible, proving that even subjected parties under article 51 (1) does not necessarily determinant in the question of legal standing. Therefore the Court would not grant legal standing even to Indonesian citizens when they do not have the possible constitutional loss.

\subsubsection{The Due Process of Law}

The Court had determined that such inadmissibility decision does not necessarily constitute the breach of due process of law principle since the applicants were granted the legal remedies of appeal, cassation and review before the Supreme Court. ${ }^{66}$ As a matter of fact, it was true that they were given their rights for legal remedies by means appeal and cassation by the time the constitutional judgment was delivered. This reasoning, however, preserved error of law.

The 1945 Constitution, in chapter IX, article $24,24 \mathrm{~A}, 24 \mathrm{~B}, 24 \mathrm{C}$ and 25 , stipulate the definition of judicial power in Indonesian legal system. Article 24 (1) defines:

(1) The judicial power shall be independent to organize judicial administration in order to uphold the law and justice.

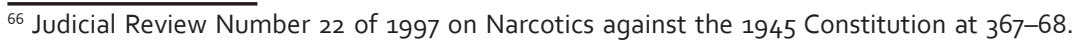


A Commentary: the Inadmissibility of Non-Indonesian Citizens in Judicial Review before the Indonesian Constitutional Court

Article 24 (2) declared that:

(2) The judicial power shall be exercised by a Supreme Court and its judiciary organs within the jurisdiction of public courts, religious court, military court, state administration court, and by a Constitutional Court.

The power of Constitutional Court, in the context of due process of law, is stipulated under article $24 \mathrm{C}(1)$, is read:

(1) The Constitutional Court shall have the authority to adjudicate at the first level and last resort of which the decision shall be final in examining the laws towards the Constitution, deciding disputes concerning state institutions authorities whose are provided by the Constitution, deciding on the dissolution of political parties, and deciding disputes concerning election result.

Pursuant to those provisions, in order to uphold the law and justice, judicial power is mandated not solely to the Supreme Court, but also to the Constitutional Court. It would be then questionable when the Court drawn its conclusion that due process of law depends merely on the Supreme Court and its lower proceedings. The judicial power, in the context of enforcing the law and seeking for justice, is mandated also to the Constitutional Court. It means that Constitutional Court serves as one of the forums available to legal subject to sought for justice, more specifically for individual, regardless its citizenship or nationality because their rights are recognized under the 1945 Constitution. Since they were subjected to be prosecuted by the law and proceeded under the Supreme Court judiciary, at the same time they should be given their constitutional rights as mandated by the 1945 Constitution as the part of due process of law. There would constitute a breach of constitutional right if non-Indonesian citizens are lacking the access to stand before the Constitutional Court for judicial review. The fact that nonIndonesian citizens were not granted legal standing to question certain provision of the laws, showed that the Court seemed to leave its mandate assigned by the 1945 Constitution.

\subsection{Conflict of Laws: The Immunity of Article 51 (1)}

This reasoning on the inadmissibility decision serves as precedent in the Constitutional Court. Some four years after the judgment No 2-3/PUU—V/2007 
delivered, the Constitution Court has unanimously rendered a judgment No 73/ PUU-VIII/2010 filed also by non-Indonesian citizen, a Romanian, Popa Nicolae, concerning on his arbitrary detention based on article 34 (b), article 35 (1), and article 39 (4) of the Indonesian Statute No 1 Year 1979 on Extradition and article 51 (1) (a) the Indonesian Statute No 24 Year 2003 concerning The Constitutional Court. The Constitutional Court declared the case inadmissible since the applicant, Romanian citizen, had no legal standing to file for such judicial review. His detention had been prolonged up to six times because the extradition law did not mention the maximum time period of the detention. ${ }^{67}$ If the ruling of the Constitutional Court is followed, it would be very difficult to find Indonesian citizens who have the similar interest as Popa Nicolae in order to fulfill the requirements of legal standing for the judicial review.

These two cases, ${ }^{68}$ along with article $5^{1}$ (1) judicial review case in $2014^{69}$, amount to immune status of article $5^{1}$ (1) from judicial review. There would be no chance to review the existence of article 51 (1) towards the 1945 Constitution. Consequently, non-Indonesian citizens will never be recognized in judicial review mechanism before the Indonesian Constitutional Court. In fact, although they possibly have constitutional injury, they cannot challenge the statute because article 51 (1) does not recognize them as the applicants at the first place. It requires to be Indonesian citizens to submit for judicial review. Meanwhile, when Indonesian citizens seeks to review article 51 (1) before the Constitutional Court they will certainly be declared inadmissible due to simply insufficient constitutional loss or injury. In this context, there is no possible entrance to review article $5^{1}$ (1) when at the same time this article is used as the basis for legal standing determination by the Court. Article 51 (1) leaves itself immune from judicial review before the Court, and this Court decision actually precludes the Court from its genuine mandate to examine the laws under the 1945 Constitution.

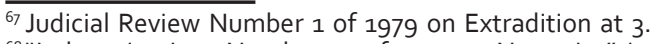

68 "Indonesian Law Number 22 of 1997 on Narcotics" (1997); Judicial Review Number 1 of 1979 on Extradition.

${ }^{6}$ Judicial Review Number 24 of 2003 on the Constitutional Court as it has been amended into Law Number 8 of 2011 on the Amendment of Law Number 24 of 2003 on the Constitutional Court against the 1945 Constitution. It reviews article 51 (1).
} 
A Commentary: the Inadmissibility of Non-Indonesian Citizens in Judicial Review before the Indonesian Constitutional Court

\section{CONCLUDING REMARK}

The determination to grant legal standing should be based on the constitutional loss of the applicant rather than on the subjected parties. The Court's decision in determining non-Indonesian citizens' legal standing based on the expressis verbis of article $5_{1}^{1}$ (1) (a) has abandoned the substance of that concerned article, the constitutional loss. This ruling, however, amounts to the error application of the 1945 Constitution and culminating to immune status of article 51 (1) from judicial review. The genuine mandate of the Court for reviewing the laws is then obscured by such determination.

As the judgment of Constitutional Court is final and not subjected for any review, there is nothing here to suggest available avenues in order to correct this ruling. In forthcoming examinations, perhaps, the judges' dissenting opinion in this case could be invoked to remind the Court for the ratio legis of judicial review.

\section{References}

Andras, Jakab. European Constitutional Language. Cambridge University Press, 2016.

Asshiddiqie, Jimly. Hukum Acara Pengujian Undang-Undang. Jakarta: Konstitusi Pers, 2006.

Bisariyadi. "Membedah Doktrin Kerugian Konstitusional." Jurnal Konstitusi 14, no. 1 (2017): 22-44.

Flethcer, George. Basic Concepts of Criminal Law. New York: Oxford University Press, 1998.

Flethcer, William. "The Structure of Standing." The Yale Law Journal 98, no. 221 (1988).

Hadjon, Philipus. Pengantar Hukum Administrasi Indonesia-Introduction to the Indonesian Administrative Law 3rd Edition. Surabaya: Gadjah Mada University Press, 1994.

Hendrianto, Stefanus. "Convergence or Borrowing: Standing in the Indonesian Constitutional Court." Constitutional Review 1, no. 1 (2015): 28-49.

Indonesian Law Number 22 of 1997 on Narcotics (1997). 
Indonesian Law Number 24 of 2003 on the Constitutional Court (2003).

Indonesian Law Number 48 of 2009 on Judicial Power (2009).

Judicial Review Number 1 of 1979 on Extradition, No. 73/PUU-VIII/2010 (The Constitutional Court of the Republic of Indonesia 2010).

Judicial Review Number 22 of 1997 on Narcotics against the 1945 Constitution, No. 2-3/PUU-V/2007 (The Constitutional Court of the Republic of Indonesia 2007).

Judicial Review Number 24 of 2003 on the Constitutional Court as it has been amended into Law Number 8 of 2011 on the Amendment of Law Number 24 of 2003 on the Constitutional Court against the 1945 Constitution, No. 137/ PUU-XII/2014 (The Constitutional Court of ther Republic of Indonesia 2014).

Judicial Review Number 32 of 2004 on Regional Government against the 1945 Constitution, No. 006/PUU-III/2005 (The Constitutional Court 2005).

Judicial Review Number 56 Prp of 1960 on the Determination of Agricultural Land Area against the 1945 Constitution, No. 11/PUU-V/2007 (The Constitutional Court of the Republic of Indonesia 2007).

Kelsen, Hans. General Theory of Law and State (2oth Century Legal Philosophy Series Vol. I). Cambridge: Harvard University Press, 1949.

- - - Pure Theory of Law (2nd German Edition Max Knight). New Jersey: The Law Book Exchange, Ltd, 2005.

Marzuki, Laica. "Legal Standing, Sisi Lain Pengujian UU Di MK." Kompas. 2004, 8 edition.

Rahardjo, Satjipto. Ilmu Hukum. 6th ed. Bandung: Citra Aditya Bakti, 2006.

Sulaiman, King Faisal. Teori Peraturan Perundang-Undangan Dan Aspek Pengujiannya. Yogyakarta: Thafa Media, 2017.

The 1945 Constitution of the Republic of Indonesia (1945). 